\title{
Nitrous oxide emissions from a New Zealand cropped soil: tillage effects, spatial and seasonal variability
}

\author{
M.A. Choudhary ${ }^{a}$, A. Akramkhanov ${ }^{b, 1}$, S. Saggar ${ }^{c, *}$ \\ ${ }^{a}$ Institute of Technology and Engineering, Massey University, Palmerston North, New Zealand \\ ${ }^{\mathrm{b}}$ Tashkent Institute of Irrigation and Agricultural Mechanisation Engineers, Tashkent, Uzbekistan \\ ${ }^{\mathrm{c}}$ Landcare Research, Private Bag 11052, Palmerston North, New Zealand
}

Received 29 August 2000; received in revised form 3 January 2002; accepted 15 January 2002

\begin{abstract}
Agricultural practices are believed to be the major anthropogenic source of enhanced nitrous oxide $\left(\mathrm{N}_{2} \mathrm{O}\right)$ gas emissions in New Zealand. Studies conducted in New Zealand generally suggest low $\mathrm{N}_{2} \mathrm{O}$ emission from pasture; however, there is little information for arable farming systems. This paper evaluates tillage and land use effects on $\mathrm{N}_{2} \mathrm{O}$ emissions using a closed chamber technique at an Ohakea silt loam (Gleyic luvisol) where winter oats (Avena sativa L.)/fodder maize (Zea mays $\mathrm{L}$.) was double-cropped for 5 years. The tillage types included conventional tillage (CT) and no-tillage (NT) systems, and a permanent pasture (PP) was used as a control.

Spatial variability in all treatments showed large inherent variations in $\mathrm{N}_{2} \mathrm{O}$ fluxes (a mean $\mathrm{CV}=119 \%$ ), which reflected natural soil heterogeneity, and perhaps the measurement technique used rather than the real differences due to the tillage and cropping systems evaluated. On an annualised basis, $\mathrm{N}_{2} \mathrm{O}$ emissions measured from December 1998 to September 1999 from the PP $\left(1.66 \mathrm{~kg} \mathrm{~N}_{2} \mathrm{O}-\mathrm{N} / \mathrm{ha}\right.$ per year or $\left.19 \mu \mathrm{g} \mathrm{N} \mathrm{N}_{2} \mathrm{O}-\mathrm{N} /\left(\mathrm{m}^{2} \mathrm{~h}\right)\right)$ were significantly lower than the CT and NT fields averaging at 9.20 (or 105) and 12.0 (or 137) $\mathrm{kg} \mathrm{N}_{2} \mathrm{O}-\mathrm{N} / \mathrm{ha} \mathrm{per} \mathrm{year} \mathrm{(or} \mu \mathrm{g} \mathrm{N}_{2} \mathrm{O}-\mathrm{N} /\left(\mathrm{m}^{2} \mathrm{~h}\right.$ )), respectively. However, there were no differences in $\mathrm{N}_{2} \mathrm{O}$ emission rates between the CT and NT treatments. Seedbed preparation using a power harrow which followed within a few days of first ploughing the $\mathrm{CT}$ field reduced $\mathrm{N}_{2} \mathrm{O}$ emissions by $65 \%$ within the first hour after power harrowing. However, $\mathrm{N}_{2} \mathrm{O}$ emission rates returned to the pre-power harrowing levels at the next sampling period, which was 1 month later.

There was a strong relationship between log-transformed data of soil water content (SWC) and $\mathrm{N}_{2} \mathrm{O}$ emissions in all treatments with $r=0.73,0.75$ and 0.86 for the PP, CT and NT treatments, respectively. Seasonal variations in $\mathrm{N}_{2} \mathrm{O}$ emission from the PP were in the order of winter $=$ autumn $>$ summer. Although fluxes in the CT were higher in winter than in the autumn season, there were no differences between the summer and autumn data. The seasonal variations in $\mathrm{N}_{2} \mathrm{O}$ emission in the NT treatment were in the order of winter $>$ autumn $=$ summer.
\end{abstract}

(c) 2002 Elsevier Science B.V. All rights reserved.

Keywords: Nitrous oxide; Greenhouse gas emissions; No-tillage; Conventional tillage; Pasture

\section{Introduction}

* Corresponding author. Tel: +64-6-356-7154; fax: +64-6-355-9230.

E-mail address: saggars@landcare.cri.nz (S. Saggar).

${ }^{1}$ Formerly at Institute of Technology and Engineering, Massey University, Palmerston North, New Zealand.
There is a growing concern worldwide about climate change. Atmospheric warming which is known to be caused by "greenhouse gases" mainly include carbon dioxide $\left(\mathrm{CO}_{2}\right)$, methane $\left(\mathrm{CH}_{4}\right)$ and 
nitrous oxide $\left(\mathrm{N}_{2} \mathrm{O}\right)$ and to a lesser extent chlorofluorocarbons (CFCs) (IAEA, 1992). The increase in greenhouse gases other than $\mathrm{CO}_{2}$ in changing the climate is similar in importance to $\mathrm{CO}_{2}$. Nitrous oxide, which despite its low concentration in the atmosphere of about $310 \mathrm{ppb}$ (IPCC, 1995), on a molecular basis has a radiative force of about 200-300 times that of $\mathrm{CO}_{2}$ (Jaques, 1992) and an average atmospheric lifetime of about 150 years (IAEA, 1992).

It is widely accepted that the main anthropogenic source of $\mathrm{N}_{2} \mathrm{O}$ is agriculture and most $\mathrm{N}_{2} \mathrm{O}$ originates as an intermediate product from microbial nitrification and denitrification (Delwiche, 1981). Increased $\mathrm{N}_{2} \mathrm{O}$ emissions from soils are associated with fertilisation of soils with mineral nitrogen $(\mathrm{N})$, animal manure, $\mathrm{N}$ derived from biological $\mathrm{N}_{2}$ fixation, and enhanced $\mathrm{N}$ mineralisation (MacKenzie et al., 1998). With fertiliser usage predicted to grow worldwide at 6-7\% per annum (Peoples et al., 1995) and low $\mathrm{N}$ utilisation efficiency in agricultural systems, the potential of soils to form and emit $\mathrm{N}_{2} \mathrm{O}$ is expected to markedly increase. Such increases in $\mathrm{N}_{2} \mathrm{O}$ emission to the atmosphere are of great concern and need quantification.

Amounts of $\mathrm{N}_{2} \mathrm{O}$ emitted depend on complex interactions between soil properties, climatic factors and agricultural practices (Granli and Bockman, 1994). Main factors in the soil controlling $\mathrm{N}_{2} \mathrm{O}$ emissions are soil content of $\mathrm{NH}_{4}{ }^{+}$and $\mathrm{NO}_{3}{ }^{-}$(Ball et al., 1997; Castaldi and Smith, 1998; Seneviratne and van Holm, 1998); soil aeration status and soil water content (SWC) (Carran et al., 1995; Teira-Esmatges et al., 1998; MacKenzie et al., 1998); presence of degradable organic material which promotes microbial activity (Ineson et al., 1998; Kaiser et al., 1998); soil pH and soil temperature (Mahmood et al., 1998). Although these are known interacting factors they are not always strongly correlated with $\mathrm{N}_{2} \mathrm{O}$ fluxes. Due to complexity of interactions between various factors, $\mathrm{N}_{2} \mathrm{O}$ emissions have very high spatial and temporal variations.

Intensive use of cultivation practices hugely impacts soil properties, which may influence the extent of $\mathrm{N}_{2} \mathrm{O}$ emissions. In the Manawatu region continuous cropping of heavier textured soils results in loss of soil organic matter (SOM) and deterioration in soil structure (Shepherd et al., 2001). Even short-term tillage operations can affect SOM levels and microbial biomass (Aslam et al., 1999), which are important in nutrient transformations. Conversion of pastures to arable cropping in New Zealand results in depletion of SOM and soil N fertility over time (Saggar et al., 2001) and additional $\mathrm{N}$ fertilisers are applied to compensate for the loss of organic $\mathrm{N}$ reserves. Since N fertilisation as a source of $\mathrm{N}$ is considered to be a major source of increasing $\mathrm{N}_{2} \mathrm{O}$ emission, careless $\mathrm{N}$ application on such soils may contribute to increased loss of $\mathrm{N}$ either as $\mathrm{NO}_{3}{ }^{-}$through leaching or as $\mathrm{N}_{2} \mathrm{O}$ emissions.

An alternative to conventional tillage (CT) is no-tillage (NT) that aims for sustainable agricultural production. A growing acceptance of NT is largely due to reduced soil erosion and runoff (Choudhary and Baker, 1993), enhanced water retention and infiltration (Choudhary et al., 1996), lower summer temperatures (Prihar et al., 1996) and possible increased net return to the farmer (Reicosky, 1994). However, the impact NT has on $\mathrm{N}_{2} \mathrm{O}$ emission is not known for these Manawatu soils.

In the past 20 years, research on $\mathrm{N}_{2} \mathrm{O}$ emissions has concentrated on enhancing our understanding of $\mathrm{N}_{2} \mathrm{O}$ production processes and its controlling factors. Despite this, it is not possible to predict the fate of a unit of $\mathrm{N}$ that is applied on a specific arable field (Mosier et al., 1996). Both short- and long-term in situ measurements are needed to assess $\mathrm{N}_{2} \mathrm{O}$ emissions from soils. Studies by Ruz-Jerez et al. (1994) and Carran et al. (1995) from both poorly and well drained grazed pastures in the Manawatu region suggest low $\mathrm{N}_{2} \mathrm{O}$ emission from these low fertility hill lands. However, there is little information for arable farming systems. Therefore, there is a need for site-specific assessment of the impact of tillage practices on $\mathrm{N}_{2} \mathrm{O}$ fluxes.

To evaluate impacts of different tillage systems and land use on $\mathrm{N}_{2} \mathrm{O}$ emissions, selected farming practices were chosen in the Manawatu region of New Zealand. The overall aim was to characterise land use practices and their effect on $\mathrm{N}_{2} \mathrm{O}$ emissions. The specific objectives of this study were: (a) to quantitatively determine the rates of $\mathrm{N}_{2} \mathrm{O}$ emissions from the $\mathrm{CT}$ and NT cropping regimes and compare these with permanent pasture (PP) fields throughout one management cycle, and (b) to measure the response of soil $\mathrm{N}_{2} \mathrm{O}$ emissions to changes in soil water and soil temperature. 


\section{Materials and methods}

\subsection{Experimental site}

The experimental site was at the Massey University, Turitea campus (latitude $40^{\circ} 21^{\prime} \mathrm{S}, 175^{\circ} 39^{\prime} \mathrm{E}$ ), on an Ohakea silt loam soil (Typic andoaqualf) classified as Gleyic luvisol (FAO). The treatments included CT, NT and rotationally sheep grazed PP used as a control (established since 1995). The CT included one mouldboard ploughing (to about $25 \mathrm{~cm}$ depth) followed by rolling with a heavy roller, and two power harrowings (to about $15 \mathrm{~cm}$ depth) at suitable intervals to prepare the seedbed. The NT used spraying with 41 of glyphosate per ha and drilling with a NT seed drill. Each treatment had four replicates in a randomised block design. Each plot was $17 \mathrm{~m}$ long and $3.6 \mathrm{~m}$ wide with a $5 \mathrm{~m}$ headland for machinery operation on both sides of the plots. In November 1998, a summer crop of fodder maize (Zea maize L.) at seed rate of $65 \mathrm{~kg} / \mathrm{ha}$ and in April 1999 a winter crop of oats (Avena sativa L.) at seed rate of $120 \mathrm{~kg} / \mathrm{ha}$ were sown on CT and NT treatments. A fertiliser Nitrophoska $(12 \% \mathrm{~N}, 10 \% \mathrm{P}, 10 \% \mathrm{~K}$, and $1 \% \mathrm{~S})$ was applied at the rate of $120 \mathrm{~kg} / \mathrm{ha}$ for fodder maize and $200 \mathrm{~kg} / \mathrm{ha}$ for oats. This was followed by a second dose of $65 \mathrm{~kg}$ urea/ha to all the treatments. Aitchison seed drill (Seedmatic 1112) was used for sowing and fertiliser application. At maturity sheep grazed both crops.

\subsection{Soil sampling}

Within each treatment, five cores $(25 \mathrm{~mm}$ diameter) were taken randomly from each depth $0-100$ and $100-200 \mathrm{~mm}$ depths and in each replicate, before spring cultivation and sowing. The cores were pooled, air-dried and sieved $(<2 \mathrm{~mm})$. Subsamples of the sieved soil were air-dried and used for $\mathrm{pH}, \mathrm{C}$ and $\mathrm{N}$ analyses.

\subsection{Soil analyses}

Air-dried samples were used for the total $\mathrm{C}$ and $\mathrm{N}$ analyses. Total $\mathrm{C}$ in soils was analysed by a combustion method (Induction Furnace, Leco, St. Joseph, Mich.). Total soil $\mathrm{N}$ was determined by semi-micro Kjeldahl digestion followed by $\mathrm{NH}_{4}{ }^{+}-\mathrm{N}$ measurements in the digests by an autoanalyser procedure.
Soil $\mathrm{pH}$ (1:2.5 water) was determined according to Blakemore et al. (1987).

SWC and temperature were measured for the 0-100 mm depth each time $\mathrm{N}_{2} \mathrm{O}$ was measured. Soil samples were collected, weighed, oven-dried to constant mass at $105^{\circ} \mathrm{C}$, and reweighed. The final mass $M_{\mathrm{s}}$, and the differences between fresh and dry masses $M_{\mathrm{W}}$ were used to calculate the gravimetric SWC:

$\mathrm{SWC}=\left(\frac{M_{\mathrm{w}}}{M_{\mathrm{S}}}\right) \times 100$

Soil temperature was measured with a handheld digital thermometer. A temperature probe was inserted into the soil next to each chamber and temperatures were recorded manually.

Soil characteristics of the site are shown in Table 1. Monthly rainfall data from 1996 to 1999 is shown in Fig. 1. Soil water (Fig. 2) and temperature at $100 \mathrm{~mm}$ depth were measured at each sampling time.

The cumulative rainfall during the study period was below the average rainfall received in most years. Rainfall distribution was particularly low during summer (December-February), with only half the normal rainfall for this season. The rainfall during the remainder of the study period was $10-20 \%$ lower than the 30 -year mean monthly values. The mean monthly air temperatures for the summer months ranged between 15 and $20^{\circ} \mathrm{C}$, and coolest temperatures were recorded in the winter months of June-August $\left(7-10^{\circ} \mathrm{C}\right)$. The annual fluctuations in soil temperature at $100 \mathrm{~mm}$ depth followed similar trends to the air temperatures, and can be considered normal for this region.

Table 1

Soil characteristics of the experimental site (Massey University research site) ${ }^{\mathrm{a}}$

\begin{tabular}{lrrrr}
\hline Characteristic & Depth $(\mathrm{mm})$ & PP & CT & \multicolumn{1}{l}{ NT } \\
\hline Total C $(\mathrm{g} / \mathrm{kg})$ & $0-100$ & 27.50 & 21.70 & 24.30 \\
& $100-200$ & 18.40 & 19.30 & 18.00 \\
Total N (g/kg) & $0-100$ & 2.40 & 2.00 & 2.20 \\
& $100-200$ & 1.70 & 1.80 & 1.70 \\
$\mathrm{pH}\left(\mathrm{H}_{2} \mathrm{O}\right)$ & $0-100$ & 5.31 & 5.30 & 5.10 \\
& $100-200$ & 5.32 & 5.26 & 5.10 \\
\hline
\end{tabular}

PP: permanent pasture; CT: conventional tillage; NT: no-tillage. a Soil type: Ohakea silt loam (Gleyic luvisol). 


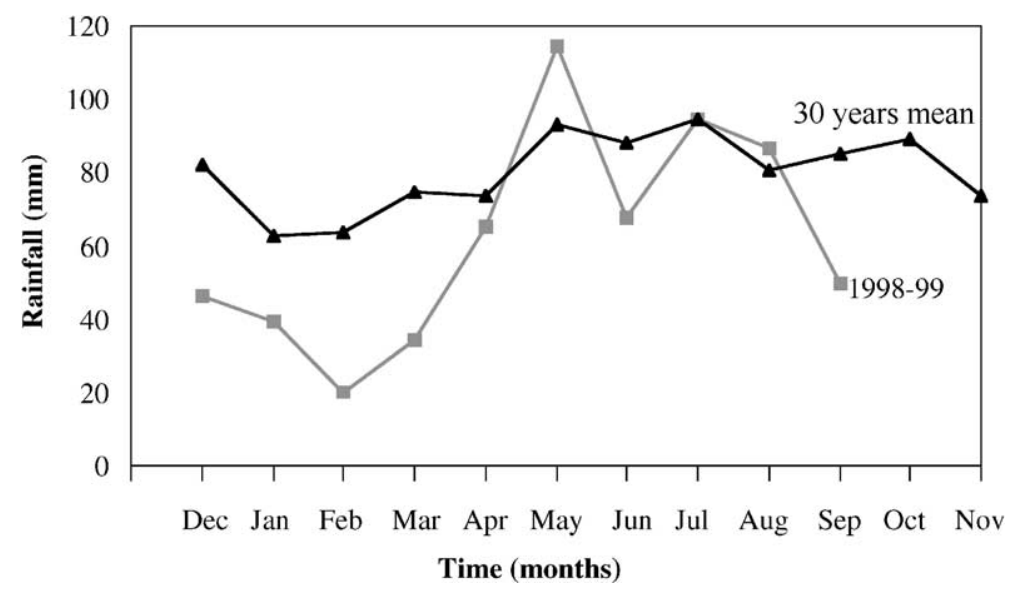

Fig. 1. Monthly rainfall from December 1998 to September 1999 and 30-year mean monthly rainfall.

\subsection{Measurement of field $\mathrm{N}_{2} \mathrm{O}$ emission}

In order to assess the effect of tillage treatments on soil $\mathrm{N}_{2} \mathrm{O}$ emissions, monthly (and occasionally fortnightly) measurements were taken during cropped as well as fallow periods. Fortnightly measurements were carried out when there was considerable weather change. The measurements at the Massey site started on 22 December 1998 and continued until 8 September
1999. During this period, a total of 10 measurements were completed. $\mathrm{N}_{2} \mathrm{O}$ measurements in May were, inadvertently, not able to be taken.

Nitrous oxide emissions were measured following the chamber technique developed by Mosier and Hutchinson (1981). The chambers were modified PVC 'Sewer-hatch' (250 mm diameter and $300 \mathrm{~mm}$ high) attached to $200 \mathrm{~mm}$ deep and $250 \mathrm{~mm}$ diameter sections of PVC pipe. The PVC rim had an internal

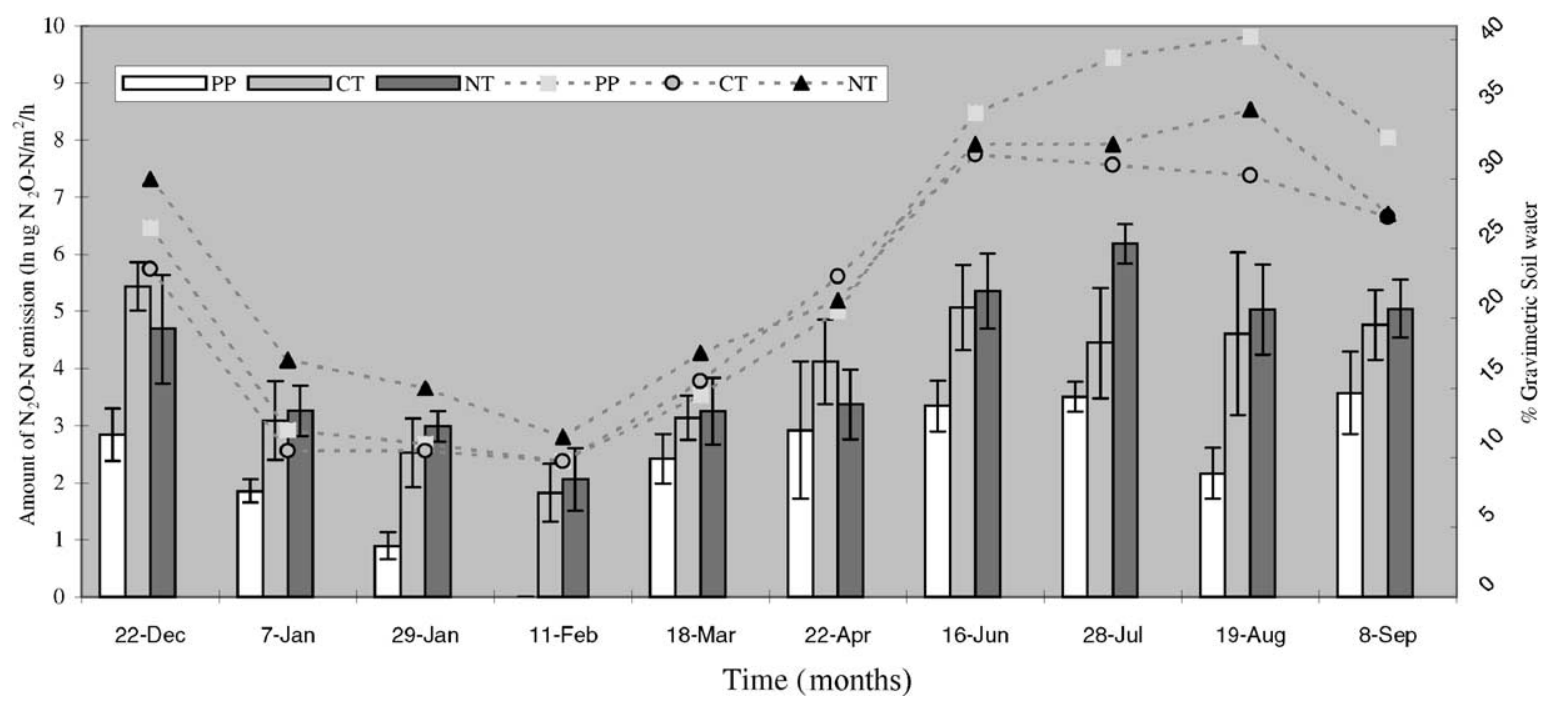

Fig. 2. Means of log-transformed (to the base e) nitrous oxide emissions ( $\mu \mathrm{g} \mathrm{N} \mathrm{N}_{2} \mathrm{O}-\mathrm{N} /\left(\mathrm{m}^{2} \mathrm{~h}\right)$ ), and gravimetric SWC. Vertical bars represent nitrous oxide flux and broken lines represent SWC. Vertical line bars show LSD values at $P<0.05$. 
half-turn locking system and a greased rubber 'O'-ring, to form an airtight chamber. At each measurement, 12 chambers, one chamber per plot (four replicates), were randomly inserted $100 \mathrm{~mm}$ into the soil $2 \mathrm{~h}$ before the measurements. Chamber heights were measured and each chamber volume calculated. The chambers were then sealed and headspace gas samples were collected using $60 \mathrm{ml}$ polypropylene syringes fitted with three-way stopcocks. Because of concern over the permeability of polypropylene to $\mathrm{N}_{2} \mathrm{O}$, field samples were analysed as soon as possible after collection, usually within $24 \mathrm{~h}$. Initially the chambers were left inserted in the soil for three hours with $1 \mathrm{~h}$ interval for air sampling in order to determine linear flux of $\mathrm{N}_{2} \mathrm{O}$ production and to detect any leakage. In later samplings, it was reduced to only $2 \mathrm{~h}$. Analyses were done using a gas chromatographic method (Mosier and Mack, 1980). Argon-methane carrier gas consisting of $10 \pm 3 \%$ methane, $<10 \mathrm{ppm}$ oxygen and $<5 \mathrm{ppm}$ water in argon was used in the columns. Gas samples from syringes were introduced into a $5 \mathrm{~cm}^{3}$ gas sampling loop. Each analysis took approximately $6 \mathrm{~min}$. Peaks were integrated with a Hewett-Packard 3385A integrator. Ambient air at $t_{0}$, collected at the time of chamber installation, was used as a reference for calculating $\mathrm{N}_{2} \mathrm{O}$ gas fluxes.

Two pilot experiments were conducted to assess (i) inherent spatial variations in $\mathrm{N}_{2} \mathrm{O}$ fluxes due to soil heterogeneity (ii) the immediate effect of soil disturbance on $\mathrm{N}_{2} \mathrm{O}$ fluxes during land preparation, after grazing fodder maize in March. $\mathrm{N}_{2} \mathrm{O}$ fluxes were first measured for few days immediately after ploughing and subsequent measurements were taken, immediately after power harrowing. To determine if a possible relationship existed between $\mathrm{N}_{2} \mathrm{O}$ fluxes and gravimetric SWC at $0-100 \mathrm{~mm}$ depth, water measurements were made on samples taken close to the installed chambers at the same time as gas emission samples were taken.

\subsection{Statistical analysis}

Soil analysis results were expressed on the basis of the oven-dry $\left(105^{\circ} \mathrm{C}\right)$ weight of the material. A general linear model (GLM) procedure was used for analysis of experimental data. An analysis of variance (ANOVA) using test of least significant difference (LSD) at 5\% confidence level was used for comparisons of treatments. Correlation of SWC and nitrous oxide fluxes was analysed by a mixed model procedure.

\section{Results and discussion}

\subsection{Spatial variability}

The first pilot experiment showed there was a large inherent variation in $\mathrm{N}_{2} \mathrm{O}$ fluxes with coefficient of variation values ranging between 110 and $127 \%$ across all treatments (Table 2), which reflected natural soil heterogeneity, and perhaps the measurement technique used rather than the real differences due to the tillage and cropping systems evaluated. Such variability in $\mathrm{N}_{2} \mathrm{O}$ flux values is not unexpected, as Carran et al. (1995) have also found large field variability in the $\mathrm{N}_{2} \mathrm{O}$ emissions because of soil heterogeneity and the episodic nature of $\mathrm{N}_{2} \mathrm{O}$ emissions. A recent study by Kessavalou et al. (1998) showed that to accurately estimate annual net greenhouse gas fluxes for an agro-ecosystem, gas flux determinations must also be made at critical times near tillage and wetting events in addition to monitoring fluxes under normal field conditions.

The second pilot study (data not presented) showed significant differences in $\mathrm{N}_{2} \mathrm{O}$ emissions between two sampling occasions. $\mathrm{N}_{2} \mathrm{O}$ fluxes measured immediately after mouldboard ploughing but before power harrowing were $64 \pm 14 \mu \mathrm{g} \mathrm{N} \mathrm{N}_{2} \mathrm{O}-\mathrm{N} /\left(\mathrm{m}^{2} \mathrm{~h}\right)$ but these

Table 2

Nitrous oxide emissions ( $\mu \mathrm{g} \mathrm{N}_{2} \mathrm{O}-\mathrm{N} / \mathrm{m}^{2}$ per day) from 12 replicate chambers showing spatial variation

\begin{tabular}{|c|c|c|c|c|c|c|c|c|c|c|c|c|c|c|}
\hline Treatment & $\mathrm{R} 1$ & $\mathrm{R} 2$ & R3 & $\mathrm{R} 4$ & R5 & R6 & R7 & $\mathrm{R} 8$ & $\mathrm{R} 9$ & $\mathrm{R} 10$ & R11 & $\mathrm{R} 12$ & Mean & $\mathrm{CV}(\%)$ \\
\hline $\mathrm{PP}$ & 456 & 134 & 144 & 696 & 43 & 62 & 166 & 67 & 790 & 67 & 24 & 36 & 223 & 120 \\
\hline $\mathrm{CT}$ & 86 & 91 & 221 & 163 & 247 & 218 & 410 & 156 & 1010 & 554 & 1594 & 168 & 413 & 110 \\
\hline NT & 341 & 2342 & 173 & 415 & 485 & 146 & 142 & 1313 & 300 & 391 & 96 & 91 & 518 & 127 \\
\hline
\end{tabular}

PP: permanent pasture; CT: conventional tillage; NT: no-tillage. 
dropped to $24 \pm 8 \mu \mathrm{g} \mathrm{N} 2 \mathrm{O}-\mathrm{N} /\left(\mathrm{m}^{2} \mathrm{~h}\right)$ when measured immediately after power harrowing. Comparison of two events showed those $\mathrm{N}_{2} \mathrm{O}$ fluxes declined by over $65 \%$ within $1 \mathrm{~h}$ after power harrowing. A similar observation was recorded by Kessavalou et al. (1998) during summer period, when $\mathrm{N}_{2} \mathrm{O}$ emissions declined by about $64 \%$ within $30 \mathrm{~min}$ following disking. These authors also noted that, although $\mathrm{N}_{2} \mathrm{O}$ emissions returned to the pre-discing level $8 \mathrm{~h}$ after discing, they declined again and remained low for the rest of the study period. The authors related these phenomena to low water filled pore space (WFPS) conditions in the top $7.6 \mathrm{~cm}$ of soil. In the present study, $\mathrm{N}_{2} \mathrm{O}$ emission rate returned to the pre-power harrowing levels at the next sampling period, 1 month after power harrowing, which most likely was associated with increased SWC.

There were marked spatial variations in $\mathrm{N}_{2} \mathrm{O}$ emissions in all treatments throughout the study period (Fig. 2). Cumulative CVs of treatments ranged from 39 to $140 \%$. This was not unexpected, as other researchers, such as Lemke et al. (1998) have reported up to $92 \%$ of the large-scale spatial variability, which the authors related to the differences in soil clay content in that experimental site. Others reported more than two times higher spatial variations in $\mathrm{N}_{2} \mathrm{O}$ data (Mahmood et al., 1998; Teira-Esmatges et al., 1998). Clayton et al. (1994) noted that $\mathrm{N}_{2} \mathrm{O}$ emissions arising from denitrification tended to be more spatially variable than those arising from the aerobic process of nitrification are. Incubations of soil with acetylene (data not reported) suggested that large $\mathrm{N}_{2} \mathrm{O}$ fluxes at the Kairanga field site can also result in high denitrification potential.

The spatial variability in denitrification could be attributed to "hot-spots" associated with high local concentrations of organic matter, nitrate level and soil condition. As Christensen and Tiedje (1998) have observed, the formation of these hot-spots was governed by the creation of anaerobic conditions due to increased respiration, following the introduction of a source of decomposable organic matter to the soil microbes. Clemens et al. (1999) have also reported similar observations.

Randomly selected sampling positions within the field could further contribute to large variability in $\mathrm{N}_{2} \mathrm{O}$ fluxes. On some sampling occasions $\mathrm{N}_{2} \mathrm{O}$ fluxes ranged almost 10 -fold with the lowest and highest recorded within the same treatment. As the plots were at approximately $4^{\circ}$ slope, the lower end of the field tended to have more biological activity since fluxes from this end were generally approximately two times greater than from the upper end of the field.

\subsection{Tillage effect on field $\mathrm{N}_{2} \mathrm{O}$ emissions}

The lowest and the highest fluxes ranged widely from 1 to $7.41 \mu \mathrm{g} \quad \mathrm{N}_{2} \mathrm{O}-\mathrm{N} /\left(\mathrm{m}^{2} \mathrm{~h}\right)$, respectively. Although soils sometimes act as a sink (Mahmood et al., 1998; Teira-Esmatges et al., 1998) there was no evidence of negative $\mathrm{N}_{2} \mathrm{O}$ fluxes in the chambers. Statistical analyses using raw data showed non-normality of error distribution and comparison of treatment means did not show real differences. The $\mathrm{N}_{2} \mathrm{O}$ emission rates were found to be log-normally distributed. Log-normally distributed $\mathrm{N}_{2} \mathrm{O}$ emission rates have also been reported by Ambus and Christensen (1994).

Further computation and interpretations of the log-transformed data highlighted differences in some samples whereas initial analysis indicated no such differences (Fig. 2). On most sampling dates, the NT and CT treatments had significantly higher $\mathrm{N}_{2} \mathrm{O}$ fluxes than those from the PP treatment. The March and April measurements showed no such difference among the treatments, which appeared to be mainly associated with high variability among the replicates in each treatment. Differences in emission values again pointed to high variability in the $\mathrm{N}_{2} \mathrm{O}$ emission data.

On an annualised basis, $\mathrm{N}_{2} \mathrm{O}$ emissions measured from December 1998 to September 1999 from the PP $\left(1.66 \mathrm{~kg} \mathrm{~N} 2 \mathrm{O}-\mathrm{N} / \mathrm{ha}\right.$ per year or $19 \mu \mathrm{g} \mathrm{N} \mathrm{N}_{2} \mathrm{O}-\mathrm{N} /\left(\mathrm{m}^{2} \mathrm{~h}\right)$ ) were significantly lower than the CT and NT fields averaging at 9.20 (or 105) and 12.0 (or 137) $\mathrm{kg}$ $\mathrm{N}_{2} \mathrm{O}-\mathrm{N} / \mathrm{ha}$ per year (or $\mu \mathrm{g} \mathrm{N}_{2} \mathrm{O}-\mathrm{N} /\left(\mathrm{m}^{2} \mathrm{~h}\right)$ ), respectively (Table 3). However, there were no differences in $\mathrm{N}_{2} \mathrm{O}$ emission rates between the CT and NT treatments. The data on seasonal $\mathrm{N}_{2} \mathrm{O}$ emissions from PP, CT and NT is summarised in Table 4. The $\mathrm{N}_{2} \mathrm{O}$ emissions during the fodder maize growth period (January-March) were generally low (see log-transformed data in Fig. 2). Starting from December when fluxes were high, with the PP, CT and NT treatments at 19,246 and $151 \mu \mathrm{g} \mathrm{N} \mathrm{N}_{2} \mathrm{O}-\mathrm{N} /\left(\mathrm{m}^{2} \mathrm{~h}\right)$, respectively, $\mathrm{N}_{2} \mathrm{O}$ emissions declined considerably culminating in the lowest emissions in all treatments 
Table 3

Effects of tillage systems on the means of $\mathrm{N}_{2} \mathrm{O}$ emissions

\begin{tabular}{lccc}
\hline Treatment & $\begin{array}{l}\mathrm{N}_{2} \mathrm{O} \text { emissions/h } \\
\left(\mu \mathrm{g} \mathrm{N}_{2} \mathrm{O}-\mathrm{N} / \mathrm{m}^{2}\right)\end{array}$ & $\begin{array}{l}\mathrm{N}_{2} \mathrm{O} \text { emissions per day } \\
\left(\mu \mathrm{g} \mathrm{N}_{2} \mathrm{O}-\mathrm{N} / \mathrm{m}^{2}\right)\end{array}$ & $\begin{array}{c}\mathrm{N}_{2} \mathrm{O} \text { emissions per year } \\
\left(\mathrm{kg} \mathrm{N} \mathrm{N}_{2} \mathrm{O}-\mathrm{N} / \mathrm{ha}\right)\end{array}$ \\
\hline PP & $19 \mathrm{~b}$ & $456 \mathrm{~b}$ & $1.66 \mathrm{~b}$ \\
CT & $105 \mathrm{a}$ & $2520 \mathrm{a}$ & $9.20 \mathrm{a}$ \\
NT & $137 \mathrm{a}$ & $3290 \mathrm{a}$ & $12.00 \mathrm{a}$ \\
\hline
\end{tabular}

Values with the same letter in each column are not significantly different $(P<0.05)$. PP: permanent pasture; CT: conventional tillage; NT: no-tillage.

in February with the PP, CT and NT at 1,7 and $9 \mu \mathrm{g}$ $\mathrm{N}_{2} \mathrm{O}-\mathrm{N} /\left(\mathrm{m}^{2} \mathrm{~h}\right)$, respectively.

It is worth noting that despite the particularly low rainfall during summer (December-February), December $\mathrm{N}_{2} \mathrm{O}$ emissions were several folds larger than those measured during January and February (Fig. 2) as the soil moisture in December was high. A similar phenomenon was recorded by Carran et al. (1995) who attributed it to the relatively large pool of both $\mathrm{NH}_{4}{ }^{+}$and $\mathrm{NO}_{3}{ }^{-}$in the soil.

This sharp decline coincided, firstly, with dry soil water conditions, which had dropped by more than half compared to December SWC (Fig. 2). This corresponded with low rainfall in February, which was only $20.1 \mathrm{~mm}$ for the month. Secondly, lowest emissions also coincided with low rainfall and high temperatures during the 1998/1999 summer (Fig. 1), which are some of the key factors controlling denitrification. Nevertheless, $\mathrm{N}_{2} \mathrm{O}$ fluxes from the CT and NT plots always remained higher than those from the PP plots.

From February onward, $\mathrm{N}_{2} \mathrm{O}$ emission rates started to gradually increase. A few days after tillage in first the week of April, gas emissions from the CT were increased significantly compared to the NT and PP plots (data not reported). Although $\mathrm{N}_{2} \mathrm{O}$ flux in the CT was 54 and $81 \%$ higher than that in the NT and $\mathrm{PP}$, respectively a day earlier, it declined sharply after seedbed preparation with power harrow. These results showed likely effects on $\mathrm{N}_{2} \mathrm{O}$ efflux of recently cultivated soil as earlier suggested by Kessavalou et al. (1998).

Gas emissions following the tillage operation and during oats crop establishment in April showed relatively, although insignificantly, higher $\mathrm{N}_{2} \mathrm{O}$ flux from the CT (55 and 62\%) as compared to the NT and PP plots, respectively. These data suggest that cultivated soil allow higher or similar $\mathrm{N}_{2} \mathrm{O}$ emissions to the NT soil during autumn season. Spring fluxes from CT were also found to be higher by MacKenzie et al. (1998). The $\mathrm{N}_{2} \mathrm{O}$ emissions (Fig. 2) from June to September (during winter and spring period) generally reflected increased microbial activity irrespective of tillage or cropping system as reported by Aslam et al. (1999). The $\mathrm{N}_{2} \mathrm{O}$ emissions during this period were consistently high reaching up to 684,741 and $69 \mu \mathrm{g} \mathrm{N} 2 \mathrm{O}-\mathrm{N} /\left(\mathrm{m}^{2} \mathrm{~h}\right)$ in the CT, NT and PP treatments, respectively (see log-transformed data in Fig. 2). The $\mathrm{PP}$, however, continued to emit lower amounts of $\mathrm{N}_{2} \mathrm{O}$ gas as compared to the NT and CT treatments even with the increased SWC. These findings support earlier suggestions by a number of researchers (Kaiser et al., 1998; Lemke et al., 1998; MacKenzie et al., 1998) who postulated that $\mathrm{N}_{2} \mathrm{O}$ emissions were significantly affected by climate.

Table 4

Seasonal field $\mathrm{N}_{2} \mathrm{O}$ emissions as affected by the PP, CT and NT treatments

\begin{tabular}{lllll}
\hline Treatment & \multicolumn{2}{l}{$\mathrm{N}_{2} \mathrm{O}$ emissions (kg N $\left.\mathrm{N}_{2} \mathrm{O} / \mathrm{N} / \mathrm{ha}\right)$} & & \\
\cline { 2 - 5 } & Summer (December-February) & Autumn (March-May) & Winter (June-August) & LSD $_{0.05}$ \\
\hline PP & $0.22 \mathrm{~b}$ & $0.29 \mathrm{a}$ & $0.55 \mathrm{a}$ & 0.12 \\
CT & $1.61 \mathrm{~b}$ & $1.53 \mathrm{~b}$ & $2.91 \mathrm{a}$ & 0.17 \\
NT & $1.15 \mathrm{~b}$ & $0.70 \mathrm{~b}$ & $6.85 \mathrm{a}$ & 0.47 \\
\hline
\end{tabular}

Values with the same letter in each row are not significantly different $(P<0.05)$. PP: permanent pasture; CT: conventional tillage; NT: no-tillage. 
The New Zealand winter is marked by low soil temperatures and high rainfall. This resulted in increased SWC. Despite low temperatures, high soil water increased $\mathrm{N}_{2} \mathrm{O}$ emissions significantly as a result of denitrification. Because $\mathrm{N}_{2} \mathrm{O}$ is a product of both nitrification and denitrification processes, nitrification was presumably the major source of summer $\mathrm{N}_{2} \mathrm{O}$ flux, as SWC during this period decreased and allowed predominantly aerobic soil conditions. Conversely, high $\mathrm{N}_{2} \mathrm{O}$ fluxes during winter (Table 4) indicated that denitrification was the major source of $\mathrm{N}_{2} \mathrm{O}$ emissions from these soils.

\subsection{Effect of soil water content (SWC) on $\mathrm{N}_{2} \mathrm{O}$ emissions}

Tillage practices generally influenced water content in all treatments during the year. The NT plots had higher SWC compared to the CT and PP plots during summer and early autumn when rainfall events were not frequent. Lower water content in the PP could be due to high transpiration rate from the growing pasture. However, during the winter period soil water in the PP was generally higher compared to the NT and $\mathrm{CT}$ plots that could be associated with generally low evapotranspiration.

Generally, SWC appeared to govern $\mathrm{N}_{2} \mathrm{O}$ emission rates. The lowest fluxes occurred when SWC was low (during summer period) and tended to increase with higher SWC during the winter period (Fig. 2). A number of regressions analyses to obtain the best-fit equation between the SWC and monthly $\mathrm{N}_{2} \mathrm{O}$ fluxes were computed. To examine these relationships further transformations were computed to observe if any relationship existed between the values of $\mathrm{N}_{2} \mathrm{O}$ fluxes and soil water (Fig. 3).

Overall, the log-transformed $\mathrm{N}_{2} \mathrm{O}$ data showed better correlation with field soil water with the PP $(r=$ $0.73)$, CT $(r=0.75)$ and NT $(r=0.86)$. This indicated that $\mathrm{SWC}$ and $\mathrm{N}_{2} \mathrm{O}$ emissions had strong relationship in all treatments. Nevertheless, a large number of samples were required to fully explain the relationship between the soil water and $\mathrm{N}_{2} \mathrm{O}$ emission rates. These relationships indicated that field SWC generally, although partially, determined the $\mathrm{N}_{2} \mathrm{O}$ emissions.

Other factors, such as soil temperature also played a role in the amount of $\mathrm{N}_{2} \mathrm{O}$ release. These data although not shown imply that in the Manawatu region of New
Zealand, the onset of rainy period is a major factor triggering $\mathrm{N}_{2} \mathrm{O}$ emissions.

\subsection{Effects of seasonal variations on $\mathrm{N}_{2} \mathrm{O}$ emissions}

Regardless of cropping and tillage management used, general seasonal patterns at this site are well defined, although 1 year data was not enough to statistically build time series. Low $\mathrm{N}_{2} \mathrm{O}$ emission values were predominant during the dry season while wet season values were considerably higher (Fig. 2). This trend was similar across all tillage treatments.

Seasonal grouping of $\mathrm{N}_{2} \mathrm{O}$ data showed significant differences in the $\mathrm{N}_{2} \mathrm{O}$ emissions in all three treatments (Table 4). Because there was only one measurement conducted in the first week of September, spring season was not included in the comparison. Seasonal variation in $\mathrm{N}_{2} \mathrm{O}$ emission from the $\mathrm{PP}$ was in the order of winter $>$ autumn $=$ summer. Similarly, although fluxes in the CT were higher in winter than in the autumn season, there were no differences between the summer and autumn data. The seasonal variations in $\mathrm{N}_{2} \mathrm{O}$ emission from the NT treatment were also in the order of winter $>$ autumn $=$ summer.

The seasonal variations (Table 4) indicated that $\mathrm{N}_{2} \mathrm{O}$ emissions were generally higher during winter as compared to summer and autumn. This could be triggered by wet weather, which was more frequent and intense generally starting from the end of autumn and continuing during winter, thus creating favourable conditions for denitrification.

The data also showed large seasonal as well as monthly variation in $\mathrm{N}_{2} \mathrm{O}$ emissions. Soil water and temperature presumably caused some of this variability. For example, $\mathrm{N}_{2} \mathrm{O}$ fluxes during the first sampling on 22 December were several orders higher than the next sampling on 7 January (Fig. 2). This suggested that high soil temperature coupled with the major rainfall event in December possibly gave bursts of $\mathrm{N}_{2} \mathrm{O}$ fluxes. Kessavalou et al. (1998) have also reported up to five-fold increase in $\mathrm{N}_{2} \mathrm{O}$ emissions following wetting. These authors had postulated that failure to include these short-lived episodic gas pulses in annual flux estimations might underestimate annual $\mathrm{N}_{2} \mathrm{O}$ loss by up to $24 \%$.

It is worth noting that when considering the 30 -year rainfall data (Fig. 1) during measurement period, it showed a clear deviation in 1998-1999 rainfall. The 

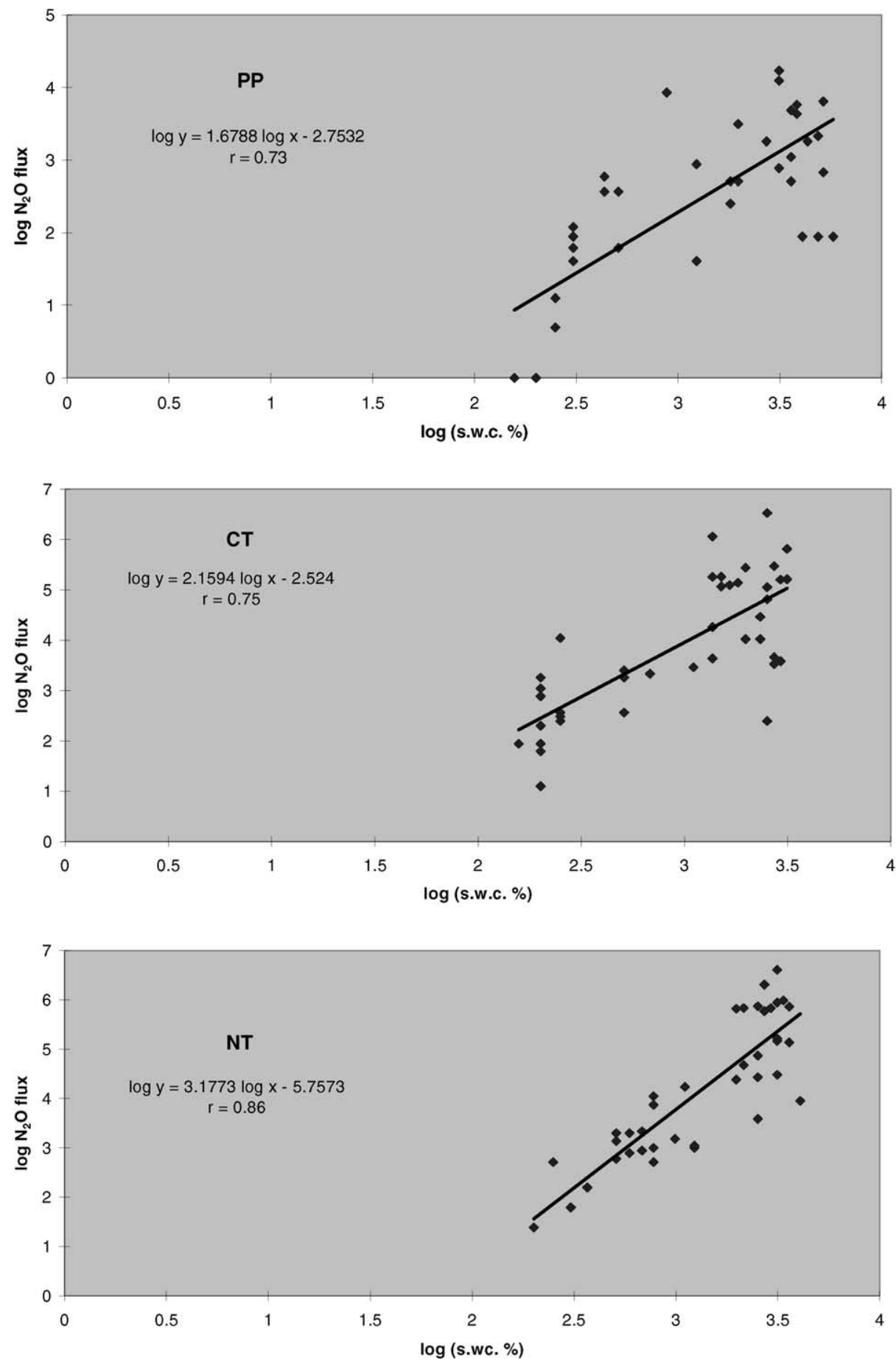

Fig. 3. Regression analysis of log-transformed (to the base e) data between SWC and $\mathrm{N}_{2} \mathrm{O}$ emissions $\left(\mu g \mathrm{~N}_{2} \mathrm{O}-\mathrm{N} /\left(\mathrm{m}^{2} \mathrm{~h}\right)\right.$ ). PP: permanent pasture; CT: conventional tillage; and NT: no-tillage; SWC: soil water content. 
cumulative rainfall during the study period was below the average rainfall received in 30 years. It was particularly low during summer (December-March) and early spring (September), with only half the normal rainfall for this season. The rainfall was 10-20\% lower during winter (April and June), and $\sim 20 \%$ higher in May than the 30-year mean monthly values. This may have had an effect on time of release and the flux magnitude of $\mathrm{N}_{2} \mathrm{O}$. Kaiser et al. (1998) found approximately $50 \%$ of the annual losses during winter period from October to February in the northern hemisphere. This highlights the importance of this period for the assessment of total $\mathrm{N}_{2} \mathrm{O}$ losses from arable lands in the temperate climate of New Zealand.

\section{Conclusions}

There was large spatial variability in the $\mathrm{N}_{2} \mathrm{O}$ data when measured in the field because of soil heterogeneity, and perhaps the measurement technique used rather than the real differences due to the tillage and cropping systems evaluated.

On an annualised basis, $\mathrm{N}_{2} \mathrm{O}$ emissions measured from December 1998 to September 1999 from the PP (1.66 kg N $2 \mathrm{O}-\mathrm{N} /$ ha per year) were significantly lower than the CT and NT fields averaging at 9.20 and $12.0 \mathrm{~kg} \mathrm{~N} 2 \mathrm{O}-\mathrm{N} / \mathrm{ha}$ per year, respectively. The $\mathrm{N}_{2} \mathrm{O}$ emissions measured from this occasionally sheep grazed PP were one-half of those reported for intensively grazed by dairy stock (Choudhary et al., 2001).

Nitrous oxide fluxes were substantially higher in the NT and CT compared to the PP treatment. However, there were no marked differences between CT and NT treatments. This indicates that conversion of pastureland to cropping significantly increases $\mathrm{N}_{2} \mathrm{O}$ emissions. The possible reason of rather low $\mathrm{N}_{2} \mathrm{O}$ emissions from the PP could be the greater nitrogen utilisation by the growing grasses, whereas in the CT and NT fields the root distribution is not as dense as proliferation of grass roots. This suggested that perhaps considerably less nitrification occurred in grassland soils than in cropped soils, allowing less opportunity for denitrification in grassland soils.

The strong correlation between $\mathrm{N}_{2} \mathrm{O}$ emissions and SWC in all treatments suggests that the high rainfall and wet winter and early spring together with soil properties, such as drainage characteristics are important in the assessment of $\mathrm{N}_{2} \mathrm{O}$ fluxes from these fields. Therefore, mitigation practices to reduce $\mathrm{N}_{2} \mathrm{O}$ emissions should be directed towards the periods of high emissions. Regardless of cropping and tillage management, general seasonal patterns at this site were obvious, although 1 year data was not enough to build statistical time series. Further extended studies with a high frequency of sampling are, therefore, necessary to confirm and obtain a robust average yearly value for New Zealand pastures grazed by sheep, sheep-beef and dairy cattle, and CT and NT soils.

\section{Acknowledgements}

Our thanks are extended to Landcare Research, Palmerston North for the use of analytical facilities, to Jacqueline Townsend and Carolyn Hedley for technical assistance, to Duncan Hedderley for assistance in data analyses, and to New Zealand Overseas Development Assistance (NZODA) for financial assistance to A. Akramkhanov.

\section{References}

Ambus, P., Christensen, S., 1994. Measurement of $\mathrm{N}_{2} \mathrm{O}$ emission from a fertilized grassland: an analysis of spatial variability. J. Geophys. Res. 99, 16549-16555.

Aslam, T., Choudhary, M.A., Saggar, S., 1999. Tillage impacts on soil microbial biomass $\mathrm{C}, \mathrm{N}$ and $\mathrm{P}$, earthworms and agronomy after 2 years of cropping following permanent pasture in New Zealand, earthworms and agronomy after 2 years of cropping following permanent pasture in New Zealand. Soil Till. Res. 51, 103-111.

Ball, B.C., Horgan, G.W., Clayton, H., Parker, J.P., 1997. Spatial variability of nitrous oxide fluxes and controlling soil and topographic properties. J. Environ. Qual. 26, 1399-1409.

Blakemore, L.C., Searle, P.L., Daly, B.K., 1987. Methods for Chemical Analysis of Soils. New Zealand Soil Bureau Scientific Report 80, p. 103.

Carran, R.A., Theobald, P.W., Evans, J.P., 1995. Emission of nitrous oxide from some grazed pasture soils in New Zealand. Aust. J. Soil Res. 33, 341-352.

Castaldi, S., Smith, K.A., 1998. The effect of different N substrates on biological $\mathrm{N}_{2} \mathrm{O}$ production from forest and agricultural light textured soils. Plant Soil 199, 229-238.

Choudhary, M.A., Baker, C.J., 1993. Conservation tillage and seeding systems in the South Pacific. Soil Till. Res. 27, 283303.

Choudhary, M.A., Lal, R., Guo, P., 1996. Tillage effects on non-point source pollution. In: Proceedings of the Conference on Engineering in Agriculture and Food Processing, Vol. 25 
(3). Gatton College, The University of Queensland, 24-27 November.

Choudhary, M.A., Akramkhanov, A., Saggar, S., 2001. Nitrous oxide emissions in soils cropped with maize under long-term tillage and under permanent pasture in New Zealand. Soil Till. Res. 62, 61-71.

Christensen, S., Tiedje, J.M., 1998. Denitrification in the field, analysis of spatial and temporal variability. In: Jenkinson, D.S., Smith, K.A. (Eds.), Nitrogen Efficiency in Agricultural Soils. Elsevier, Amsterdam, pp. 295-301.

Clayton, H., Arah, J.R.M., Smith, K.A., 1994. Measurement of nitrous oxide emissions from fertilized grassland using closed chambers. J. Geophys. Res. 99, 16599-16607.

Clemens, J., Schillinger, M.P., Goldbach, H., Huwe, B., 1999. Spatial variability of $\mathrm{N}_{2} \mathrm{O}$ emissions and soil parameters of an arable silt loam-a field study. Biol. Fertil. Soils 28, 403-406.

Delwiche, C.C., 1981. The nitrogen cycle and nitrous oxide. In: Delwiche, C.C. (Ed.), Denitrification, Nitrification, and Atmospheric Nitrous Oxide. Wiley, New York, pp. 1-15.

Granli, T., Bockman, O.C., 1994. Nitrous oxide from agriculture. Norwegian J. Agric. Sci. 12 (Suppl.), 7-128.

Ineson, P., Coward, P.A., Hartwig, U.A., 1998. Soil gas fluxes of $\mathrm{N}_{2} \mathrm{O}, \mathrm{CH}_{4}$ and $\mathrm{CO}_{2}$ beneath Lolium perenne under elevated $\mathrm{CO}_{2}$ : the Swiss free air carbon dioxide enrichment experiment. Plant Soil 198, 89-95.

International Atomic Energy Agency (IAEA), 1992. Manual on Measurements of Methane and Nitrous Oxide Emissions from Agriculture. IAEA-TECDOC-674.

Intergovernmental Panel on Climate Change (IPCC), 1995. Greenhouse gases and aerosols. Climate Change. Cambridge University Press, Cambridge, pp. 1-41.

Jaques, A.P., 1992. Canada's Greenhouse Gas Emissions: Estimates for 1990. Report Environmental Protection Series (EPS) 5/AP/4, $78 \mathrm{pp}$.

Kaiser, E.A., Kohrs, K., Kucke, M., Schnug, E., Heinemeyer, O., Munch, J.C., 1998. Nitrous oxide release from arable soil: importance of $\mathrm{N}$ fertilization, crops and temporal variation. Soil Biol. Biochem. 30, 1553-1563.

Kessavalou, A., Doran, J.W., Mosier, A.R., Drijber, R.A., 1998. Greenhouse gas fluxes following tillage and wetting in a wheat-fallow cropping system. J. Environ. Qual. 27, 11051116.

Lemke, R.L., Izaurralde, R.C., Malhi, S.S., Arshad, M.A., Nyborg, M., 1998. Nitrous oxide emissions from agricultural soils of the Boreal and Parkland regions of Alberta. Soil Sci. Soc., Am. J. 62, 1096-1102.

MacKenzie, A.F., Fan, M.X., Cadrin, F., 1998. Nitrous oxide emission in 3 years as affected by tillage, corn-soybean-alfalfa rotations, and nitrogen fertilization. J. Environ. Qual. 27, 698703.

Mahmood, T., Ali, R., Malik, K.A., Shamsi, S.R.A., 1998. Nitrous oxide emissions from an irrigated sandy-clay loam cropped to maize and wheat. Biol. Fertil. Soils 27, 189-196.

Mosier, A.R., Hutchinson, G.L., 1981. Nitrous oxide emissions from cropped fields. J. Environ. Qual. 10, 169-173.

Mosier, A.R., Mack, L., 1980. Gas chromatographic system for precise, rapid analysis of nitrous oxide. Soil Sci. Soc., Am. J. 44, 1121-1123.

Mosier, A.R., Duxbury, J.M., Freney, J.R., Heinemeyer, O., Minami, K., 1996. Nitrous oxide emissions from agricultural fields: assessment, measurement and irrigation. Plant Soil 181, 95-118.

Peoples, M.B., Mosier, A.R., Freney, J.R., 1995. Minimizing gaseous losses of nitrogen. In: Bacon, P.E. (Ed.), Nitrogen Fertilization in the Environment. pp. 565-602.

Prihar, S.S., Jalota, S.K., Steiner, J.L., 1996. Residue management for reducing evaporation in relation to soil type and evaporativity. Soil Use Manage. 12, 150-157.

Reicosky, D.C., 1994. Crop residue management: soil, crop, climate interactions. In: Hatfield, J.L., Stewart, B.A. (Eds.), Crops Residue Management. Lewis Publishers Boca Raton, FL.

Ruz-Jerez, B.E., White, R.E., Ball, P.R., 1994. Long-term measurement of denitrification in three contrasting pastures grazed by sheep. Soil Biol. Biochem. 26, 29-39.

Saggar, S., Yeates, G.W., Shepherd, T.G., 2001. Cultivation effects on soil biological properties, microfouna and organic matter dynamics in Eutric Gleysol and Gleyic Luvisol soils in New Zealand. Soil Till. Res. 58, 55-68.

Seneviratne, G., van Holm, L.H.J., 1998. $\mathrm{CO}_{2}, \mathrm{CH}_{2}$ and $\mathrm{N}_{2} \mathrm{O}$ emissions from a wetted tropical upland soil following surface mulch application. Soil Biol. Biochem. 30, 1619-1622.

Shepherd, T.G., Saggar, S., Newman, R.H., Ross, C.W., Dando, J.L., 2001. Tillage induced changes to soil structure and organic carbon fractions in New Zealand soils. Aust. J. Soil Res. 39, 465-489.

Teira-Esmatges, M.R., van Cleemput, O, Porta-Casanellas, J., 1998. Fluxes of nitrous oxide and molecular nitrogen from irrigated soils of Catalonia (Spain). J. Environ. Qual. 27, 687-697. 